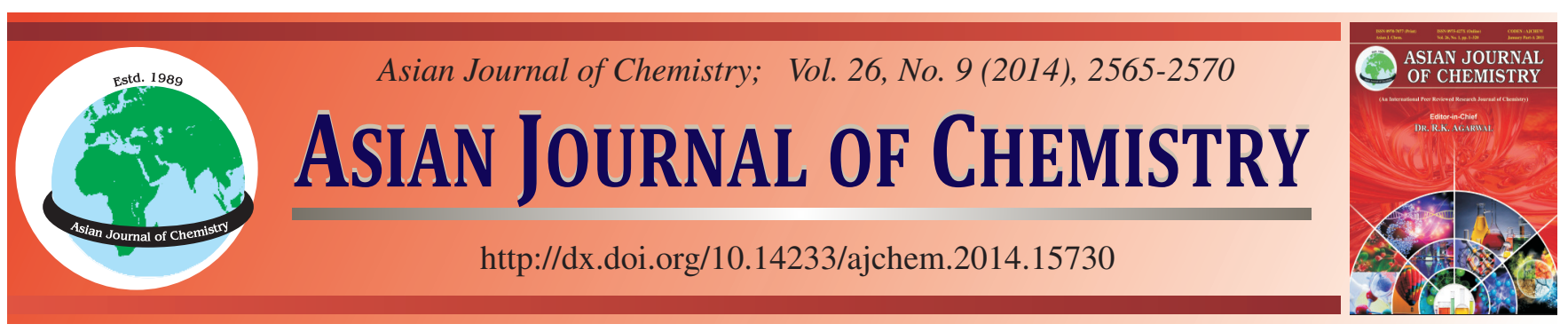

\title{
Carbon Anode for the Formation of Carbon Monoxide and its Impact on the Molten-salt Electrolysis
}

\author{
Ze-QuAn Li* ${ }^{*}$ Jing GuO, Rong Hu, Li-yue Ru and HaI-HuA Wang
}

College of Chemistry and Chemical Engineering, Chongqing University, Chongqing 400044, P.R. China

*Corresponding author: Tel: +86 23 65106053; E-mail: lzq0313@cqu.edu.cn

\begin{abstract}
Based on the theoretical calculation and experimental investigation, the formation of carbon monoxide in off-gas and its impact on molten-salt electrolysis of $\mathrm{TiO}_{2}$ were first studied. Flue gas analyzer was used to detect $\mathrm{CO}$ content in off-gas of the molten-salt electrolysis. $\mathrm{X}$-ray diffraction was used to determine the phase composition of the products of electrolysis. It indicated that the $\mathrm{CO}$ is formed by the two ways. A part of $\mathrm{CO}$ is formed by the reaction between carbon and oxygen gas, which is the main anodic reaction. The other part of $\mathrm{CO}$ is generated by the side reactions. The results showed that the $\mathrm{CO}$ and $\mathrm{CO}_{2}$ cannot vent timely so as to cause the side reactions, such that influence the efficiency of electrolysis and the purity of cathode products.
\end{abstract}

Keywords: Molten-salt electrolysis, Off-gas, CO, Formation, Influence.

\section{INTRODUCTION}

The FFC (Fray-Farthing-Chen) Cambridge process $^{1}$ is a kind of novel molten salt electrolysis method, where solid metals/semi-metals oxide, sulfide, carbide or their mixture act as cathode and thus metals/semi-metals, their alloys or intermetallic compounds are achieved on cathode and $\mathrm{O}_{2}, \mathrm{CO}_{2}$ or $\mathrm{CO}$ gas is obtained on anode under argon atmosphere.

In past decade, many scientists utilized this method to successfully prepare IIB $\left(\mathrm{Cu}^{2}\right)$, IIIB [lanthanide series $\left(\mathrm{Ce}^{3}\right.$, $\left.\mathrm{Pr}^{4}, \mathrm{~Tb}^{5}, \mathrm{Dy}^{6}\right)$, actinide series $\left.\left(\mathrm{U}^{7}\right)\right]$, VIB $\left(\mathrm{Ti}^{1,8-15}, \mathrm{Zr}^{10,16,17}\right.$, $\left.\mathrm{Hf}^{18}\right)$, VB $\left(\mathrm{V}^{19}, \mathrm{Nb}^{20,21}, \mathrm{Ta}^{22,23}\right)$, VIB $\left(\mathrm{Cr}^{24-26}, \mathrm{Mo}^{27}, \mathrm{~W}^{28,29}\right)$, VIII $\left(\mathrm{Fe}^{12,30-32}, \mathrm{Ni}^{33}\right)$, IIIA $\left(\mathrm{Al}^{34}\right)$, IVA $\left(\mathrm{Si}^{35-38}, \mathrm{Sn}^{12}\right)$ etc., metals semimetals. $\mathrm{TiW}^{39}, \mathrm{TiMo}^{40}, \mathrm{Ti}_{5} \mathrm{Si}_{3}{ }^{41}, \mathrm{TiZr}^{10,42}, \mathrm{TiFe}^{43,44}, \mathrm{NiTi}^{45}, \mathrm{Ni}-$

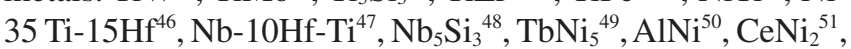
$\mathrm{CeNi}_{4} \mathrm{Cu}^{52}, \mathrm{CeCo}_{5}{ }^{53}, \mathrm{CoCr}^{54}, \mathrm{CaB}_{6}{ }^{55}$, etc. alloys/intermetallic compounds. Although a large number of metals and alloys have been electrolyzed successfully in the laboratory, the low electrolytic efficiency and the impurity of the electrolysis products still limited further application. Ge et al. ${ }^{2}$ electrolyzed copper ore at $2.8 \mathrm{~V}$, the current efficiency was estimated to $16.56 \%$ for $20 \mathrm{~h}$. Claux et $\mathrm{al}^{3}{ }^{3}$ pointed out that the electroreduction process has a poor current efficiency, only $10 \%$ of the current was used to convert $\mathrm{CeO}_{2}$ into $\mathrm{Ce}$ metal. Fray et al. ${ }^{9}$ improved the current efficiency to $32 \%$, through used a more moderate cathode potential of $-1.4 \mathrm{~V}$. Gibilaro et al. ${ }^{12}$ found that the current efficiency was quite low, around $25 \%$, for the fully reduced $\mathrm{TiO}_{2}$ sample. Chen et al. ${ }^{25}$ reported that the current efficiency was only $22 \%$ in used FFC to electrolyze the $\mathrm{Cr}_{2} \mathrm{O}_{3}$ for $6 \mathrm{~h}$. Wang and $\mathrm{Zhai}^{55}$ found that the current efficiency was only $22.7 \%$ in the molten salt electrolysis prepared $\mathrm{CaB}_{6}$. Li et al. ${ }^{56}$ reported that $\mathrm{O}^{2-}$ diffusion and the anode materials could be the main factors affecting the electrolysis efficiency and they could limit the exclusion of the same kind of ions and the attraction of the opposite ions in $\mathrm{O}^{2-}$ diffusion process. Li et al. ${ }^{57}$ analyzed the $\mathrm{C}$ contamination of the molten-salt electrolysis preparation of $\mathrm{Ti}$ and they considered that the electrolysis conditions and $\mathrm{CO}_{2}$ production could affect $C$ content of products. Some scientists ${ }^{11,16,40,58}$ found that $\mathrm{MC}$ particles were observed on the surfaces of the samples when FFC method was used to electrolyze $\mathrm{M}_{2} \mathrm{O}_{\mathrm{x}}$ to metal $\mathrm{M}$, the formation of $\mathrm{MC}$ may be described by the following reactions:

$$
\begin{gathered}
\mathrm{CO}_{2}+\mathrm{O}^{2-}=\mathrm{CO}_{2}^{2-} \\
\mathrm{CO}_{3}^{2-}+\mathrm{M}+4 \mathrm{e}^{-}=3 \mathrm{O}^{2-}+\mathrm{MC}
\end{gathered}
$$

Claux et $\mathrm{al}^{3}{ }^{3}$ reported that there was insoluble calcium carbonate at the bottom of the crucible in the preparation of cerium by electrochemical reduction of cerium oxide. So the off-gas is the influence factor of the electrolysis efficiency and products purity.

$\mathrm{Pt}^{59}, \mathrm{Au}^{12,60}, \mathrm{Ta}^{61}$ and $\mathrm{SnO}_{2}{ }^{62}$, etc. non-carbon anode were used to prevent $\mathrm{CO}_{2}$ or $\mathrm{CO}$ to generate, but these anodes are either corroded or too much expensive. Cai et al. ${ }^{19}$ regarded that the graphite anode has the obvious advantage on reducing the theoretical decomposition voltage. So this paper chose the 
graphite anode. In view of the formation of off-gas and its influence on the electrolysis efficiency and products purity exist in all kinds of metals and alloys forming process by molten-salt electrolysis and have the same formation way and influence mechanism. So we chose electrolytic titanium as a representative to do research.

As is well-known, the main components of the off-gas are $\mathrm{CO}$ and $\mathrm{CO}_{2}$ when the anode is carbon material. If we can know the $\mathrm{CO}$ content changes in off-gas, it can be used to analyze the source of $\mathrm{CO}$ and then can understand the off-gas how to influence the electrolysis. So in this paper, we investigated the formation of the $\mathrm{CO}$ in off-gas and its impact on the molten-salt electrolysis using graphite anode and exploratory studied the corresponding possible solutions.

\section{EXPERIMENTAL}

In order to eliminate the effects of trace impurities of oxygen, moisture and carbon dioxide, argon gas was pretreated through silica gel (with open porous structure, strong adsorption), calcium chloride and soda lime (porous, the main component is the calcium oxide and sodium hydroxide) three stages.

$\mathrm{TiO}_{2}$ (AR. $99.9 \%$ ) powder mixed uniformly with proper amount binder was used and then it was molded into discs by axial mould pressing at $40 \mathrm{MPa}$. The $\mathrm{TiO}_{2}$ discs were dried for $24 \mathrm{~h}$ at the room temperature and the dried discs were sintered in argon atmosphere for $4 \mathrm{~h}$ at $900{ }^{\circ} \mathrm{C}$ in tubular resistance furnace with a heating slope of $4{ }^{\circ} \mathrm{C} / \mathrm{min}$.

The sintered $\mathrm{TiO}_{2}$ samples were attached onto a molybdenum cathodic current collector to form an assembled oxide cathode and graphite rod was used as anode and then the whole process was performed in $\mathrm{CaCl}_{2}$ fused salt contained in graphite crucible under argon atmosphere with a heating rate of $4{ }^{\circ} \mathrm{C} / \mathrm{min}$. The detailed experimental procedure was as following: Firstly, it was heated to $373 \mathrm{~K}$ and held at $373 \mathrm{~K}$ for $1 \mathrm{~h}$, then heated to $573 \mathrm{~K}$ and heated preservation at $573 \mathrm{~K}$ for $2 \mathrm{~h}$; Secondly, when the temperature was raised to $1123 \mathrm{~K}$, the pre-electrolysis was proceeded at controlled potentials of $2.8 \mathrm{~V}$ for $2 \mathrm{~h}$; Thirdly, electrolysis was carried out at constant voltage $3.2 \mathrm{~V}$ at 1173 $\mathrm{K}$ for $10 \mathrm{~h}$; Lastly, after electrolysis, the discs were lifted out of the molten $\mathrm{CaCl}_{2}$ to cool to room temperature in hearth under argon atmosphere. The cathode products were then taken out of the reactor at room temperature and were washed extensively in water and then dilute hydrochloric acid and subjected to an ultrasonic treatment. Fig. 1 shows the schematic diagram of the molten salt electrolysis.

The phase compositions of the electrolyzed cathode product were tested by X-ray diffraction analysis (XRD-6000, Shimadzu), using $\mathrm{Cu}-\mathrm{K}_{\alpha}$ radiation. The $\mathrm{CO}$ content of Offgas was analyzed by flue gas analyzer (Testo-350-Pro, Testo), the sampling flow was for $0.5 \mathrm{~L} / \mathrm{min}$.

\section{RESULTS AND DISCUSSION}

Fig. 2 shows the XRD patterns of the $\mathrm{TiO}_{2}$ deoxidized for $4,6,8,10 \mathrm{~h}$ at $900{ }^{\circ} \mathrm{C}$ at $3.2 \mathrm{~V}$.

As is shown in Fig. 2, the electrolytic products are mainly $\mathrm{CaTiO}_{3}, \mathrm{Ti}_{2} \mathrm{O}$ at $4 \mathrm{~h}$ and $\mathrm{Ti}_{3} \mathrm{O}$, without $\mathrm{CaTiO}_{3}$ at $6 \mathrm{~h}$ and $\mathrm{Ti}_{3} \mathrm{O}$ after $8 \mathrm{~h}$ electrolysis and $\mathrm{Ti}, \mathrm{TiC}$ at $10 \mathrm{~h}$. These imply that the

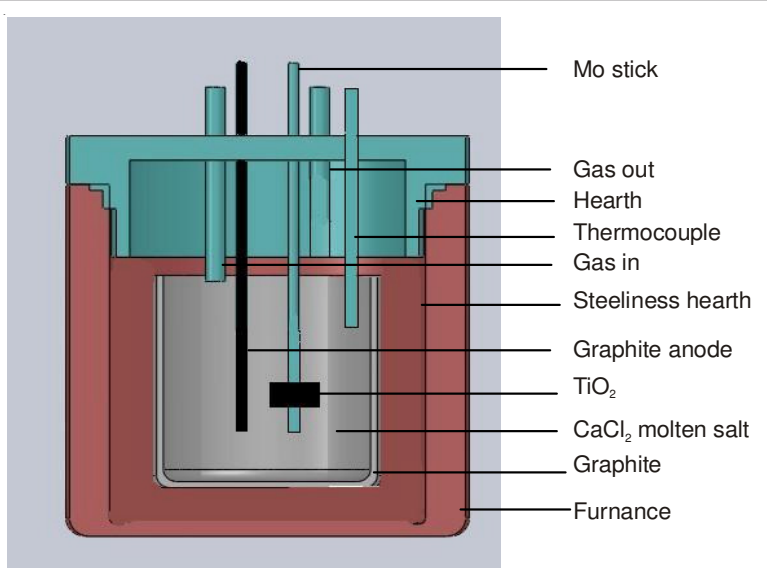

Fig. 1. Schematic diagram of the molten salt electrolysis

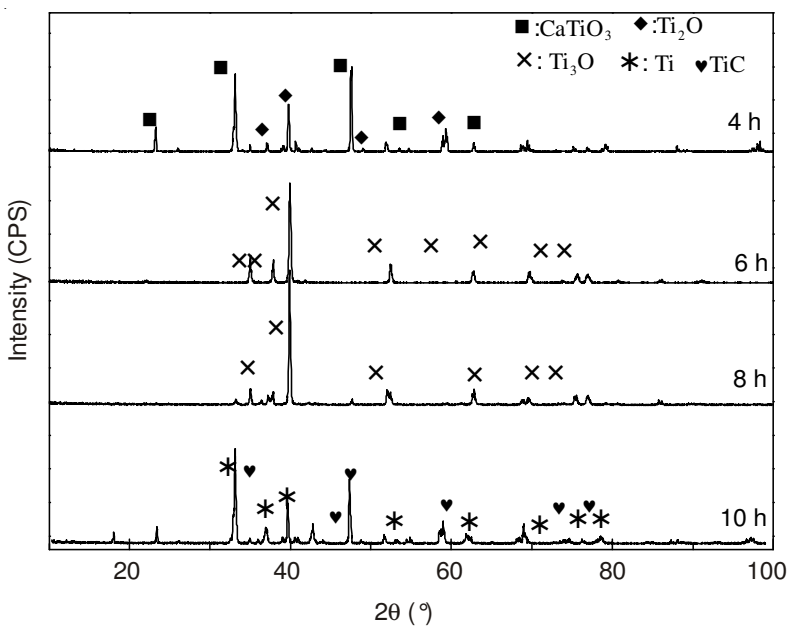

Fig. 2. XRD patterns of the discs deoxidized at $1173 \mathrm{~K}, 3.2 \mathrm{~V}$ for different time

reduction of $\mathrm{TiO}_{2}$ is subjected to a gradual reduction process and $\mathrm{CaTiO}_{3}$ is the intermediate. Fig. 2 shows the presence of $\mathrm{TiC}$, this indicates that there is some side reaction, which pollutes the cathode products.

Carbon monoxide content in off-gas: Fig. 3 displays the $\mathrm{CO}$ content and current vary with time during electrolysis at $1173 \mathrm{~K}$. As shown in Fig. 3, the black solid line is CO content curve which is subjected to a decreased period (the previous $1 \mathrm{~h}$ ) followed by an increased period, the blue solid line is the current curve which may be divided into the fast decline (from 0 to $150 \mathrm{~min}$ ), first sudden increase and then decrease (from 150 to $330 \mathrm{~min}$ ), basically constant and so on three stages. The relationship between current and CO content at different time as displayed in Fig. 3 (Table-1).

Theoretical calculation and analysis: As is well known, when carbon material is used to anode during molten electrolysis, there are three possible reactions expressed as follows.

$$
\begin{gathered}
\mathrm{C}+\mathrm{O}_{2}=\mathrm{CO}_{2} \\
2 \mathrm{C}+\mathrm{O}_{2}=2 \mathrm{CO} \\
\mathrm{C}+\mathrm{CO}_{2}=2 \mathrm{CO}
\end{gathered}
$$

According to the formula:

$$
\begin{gathered}
\Delta_{\mathrm{r}} \mathrm{G}_{\mathrm{m}}^{\theta}(\mathrm{T})=\Delta_{\mathrm{r}} \mathrm{H}_{\mathrm{m}}^{\theta}(198.15 \mathrm{~K})-\mathrm{T} \Delta_{\mathrm{r}} \mathrm{S}_{\mathrm{m}}^{\theta}(298.15 \mathrm{~K}) \\
\int_{298.15}^{\mathrm{T}} \Delta \mathrm{C}_{\mathrm{p}} \mathrm{dT}-\mathrm{T} \int_{298.15}^{\mathrm{T}} \frac{\Delta \mathrm{C}_{\mathrm{p}}}{\mathrm{T}} \mathrm{dT}
\end{gathered}
$$




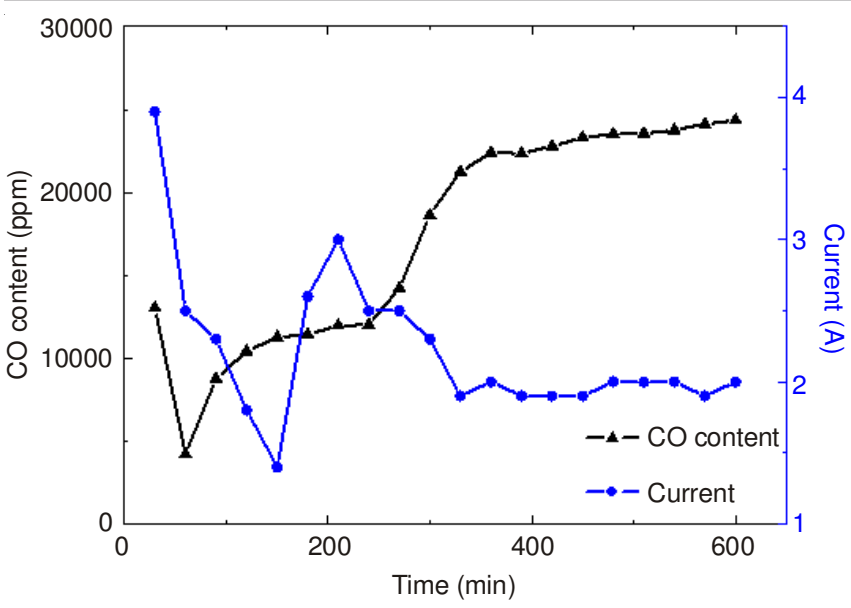

Fig. 3. CO content and current vary with time at $1173 \mathrm{~K}$

\begin{tabular}{ccc}
\multicolumn{4}{c}{ TABLE-1 } \\
\multicolumn{2}{c}{ RELATIONSHIP BETWEEN CURRENT AND CO } \\
CONTENT AT DIFFERENT TIME \\
\hline Time (min) & Current change & CO content change \\
\hline $0-60$ & decrease & decrease \\
$60-150$ & decrease & increase \\
$150-210$ & increase & increase \\
$210-330$ & decrease & increase \\
$330-600$ & constant & increase \\
\hline
\end{tabular}

where, $\Delta_{\mathrm{r}} \mathrm{G}_{\mathrm{m}}^{\theta}(\mathrm{T})$ is the Gibbs free energy change, $\Delta_{\mathrm{r}} \mathrm{H}_{\mathrm{m}}^{\theta}(\mathrm{T})$ is the enthalpy change, $\mathrm{T}$ is the reaction temperature, $\Delta_{\mathrm{r}} \mathrm{S}_{\mathrm{m}}^{\theta}(\mathrm{T})$ is the entropy change, $\Delta \mathrm{C}_{\mathrm{p}}$ is the constant pressure heat capacity change. Utilizing the basic thermodynamic data ${ }^{63}, \Delta_{\mathrm{r}} \mathrm{G}_{\mathrm{m}}^{\theta}(\mathrm{T})$ the of the above reaction (1), (2) and (3) are surveyed within the experimental temperature range and the results are shown in Fig. 4.

As shown in Fig. 4, $\Delta_{\mathrm{r}} \mathrm{G}_{\mathrm{m}}^{\theta}$ the value of reaction (1), (2) and (3) are negative, so these three reactions can occur. When temperature is below $981 \mathrm{~K}, \Delta_{\mathrm{r}} \mathrm{G}_{\mathrm{m}}^{\theta}(1)<\Delta_{\mathrm{r}} \mathrm{G}_{\mathrm{m}}^{\theta}(3)$, hence the reaction (1) is more easier to happen than that of the reaction

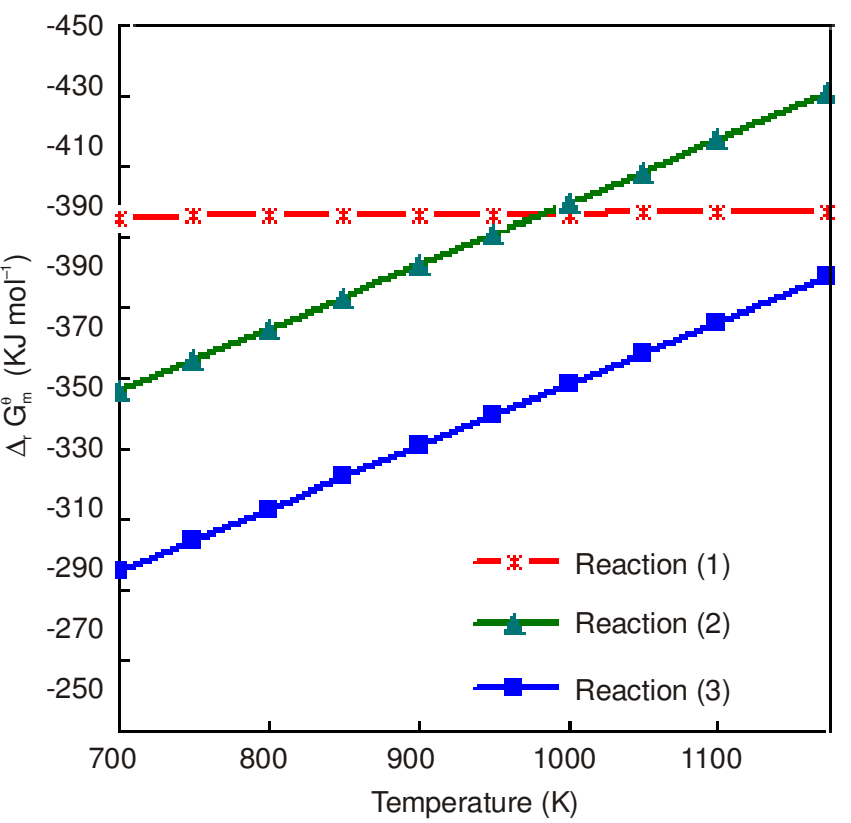

Fig. 4. Relationship between $\Delta_{\mathrm{r}} \mathrm{G}_{\mathrm{m}}^{\theta}-\mathrm{T}$

(2) and (3), so $\mathrm{CO}_{2}$ is mainly generated in this temperature range. However as temperature is higher than $981 \mathrm{~K}$, $\Delta_{\mathrm{r}} \mathrm{G}_{\mathrm{m}}^{\theta}(2)<\Delta_{\mathrm{r}} \mathrm{G}_{\mathrm{m}}^{\theta}(1)<\Delta_{\mathrm{r}} \mathrm{G}_{\mathrm{m}}^{\theta}$ (3), hence the reaction (2) is more easier to occur than that of the reaction (1) and (3) and then $\mathrm{CO}$ is mainly obtained in this temperature range.

As is well known, the current is in direct proportion to the migration amount of $\mathrm{O}^{2-}$ at the same experimental condition. So the bigger the value of current is, the more the generated $\mathrm{O}_{2}$ is. As mentioned above, the reaction (1), (2) and (3) can happen at $1173 \mathrm{k}$, what is more, the reaction (2) is easier to occur than that of the reaction (1) and (3) and then $\mathrm{CO}$ is mainly obtained in this temperature range. And such that the $\mathrm{CO}$ and $\mathrm{CO}_{2}$ content vary with the current if there aren't other side reactions, in other words, the $\mathrm{CO}$ content increase with the increase of the value of current or decrease with the decrease of the value of current. However that is not true as

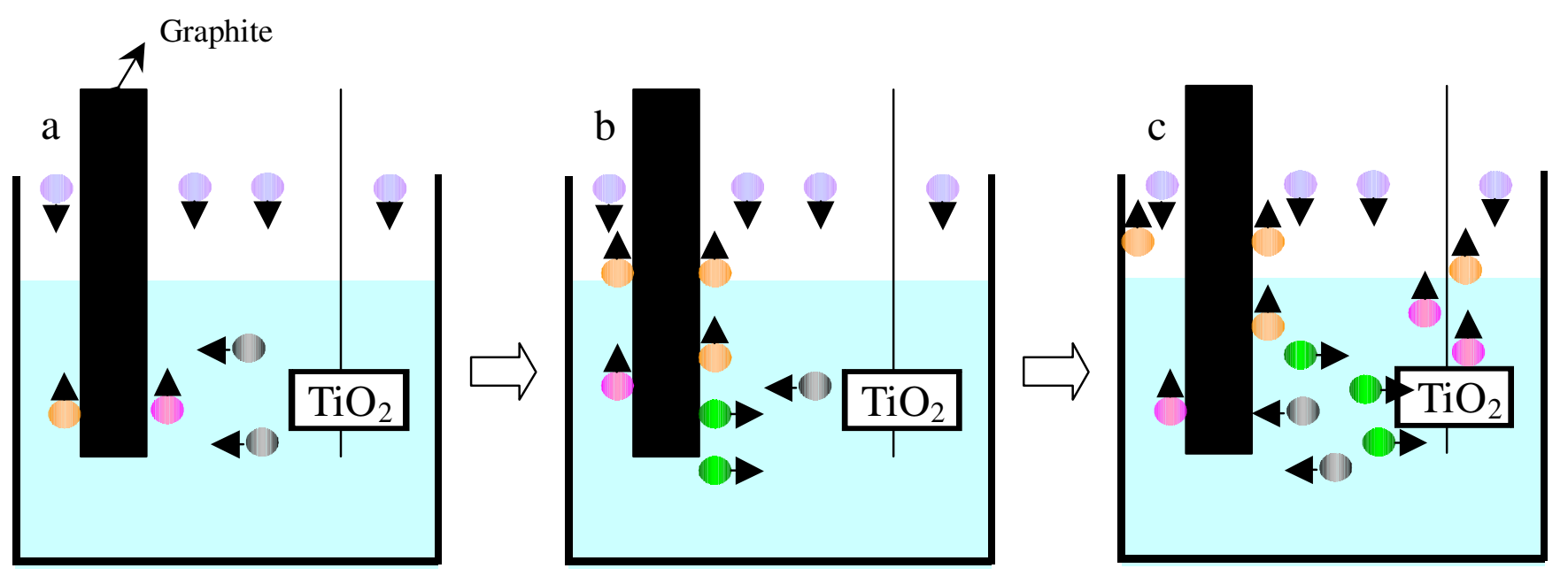

: $\mathrm{Ar} O: \mathrm{O}^{2-} \mathrm{O}: \mathrm{CO}_{2} \mathrm{O}: \mathrm{CO} \mathrm{O}: \mathrm{CO}_{3}{ }^{2-}$

Fig. 5. Schematic diagram of the formation and change of gas generated in molten salt 
detailed in Fig. 3 and Table-1, this indicates that there are some other side reactions which cause the change of the $\mathrm{CO}$ content.

Formation of $\mathrm{CO}$ and its influence: In electrolysis stage, the formation and change of gas is shown in Fig. 5.

As is shown in Fig. 5, the formation of the gas in electrolysis system underwent the following three steps diagramed from Fig. 5a, to Fig. 5b and to Fig. 5c. Firstly, the $\mathrm{O}^{2-}$ is transferred by diffusion and electromigration in the molten salt from cathode to anode and then it loses electrons to form $\mathrm{O}_{2}$ at anode. Then reactions (1) and (2) occur, which generate $\mathrm{CO}_{2}$ and $\mathrm{CO}$ around the anode just as Fig. 5a, some of them vent to the hearth, another part of them is left in molten near the anode. Secondly, the reaction (3) occurs when certain amounts of $\mathrm{CO}_{2}$ absorb around the graphite anode and thus more $\mathrm{CO}$ obtains in molten near the anode. The $\mathrm{CO}_{2}$ and $\mathrm{CO}$ gas molecules left in the molten salt around anode are mainly transferred by diffusion from anode region to cathode region. The reaction (5) can happen when the $\mathrm{CO}$ runs into $\mathrm{Ti}$ at cathode and then pollutes the product. When the $\mathrm{CO}_{2}$ meets with the $\mathrm{O}^{2-}$ departed from the cathode in molten salt, the reaction (6) can occur.

$$
\begin{gathered}
\mathrm{Ti}+\mathrm{CO}=\mathrm{TiC}+\mathrm{CO}_{2} \\
\mathrm{CO}_{2}+\mathrm{O}^{2-}=\mathrm{CO}_{3}^{2-} \\
\mathrm{CO}_{3}^{2-}+4 \mathrm{e}^{-}=\mathrm{C}+3 \mathrm{O}^{2-} \\
\mathrm{TiO}_{2}+3 \mathrm{C}=\mathrm{TiC}+2 \mathrm{CO} \\
\mathrm{C}+\mathrm{Ti}=\mathrm{TiC}
\end{gathered}
$$

Thirdly, the generated $\mathrm{CO}_{3}^{2-}$ by reaction (6) spreads to the cathode and the reduction reaction $(7)^{64,65}$ maybe happen and then the reaction (8) and (9) and so on side reactions also maybe occur, which pollute the products.

Fig. 2 doesn't show the presence of TiC at previous $8 \mathrm{~h}$ electrolysis, this indicates that the reaction (8) and (9) can't happen before $8 \mathrm{~h}$. Meanwhile there is no $\mathrm{TiO}_{2}$ after $4 \mathrm{~h}$ as shown in Fig. 2, this implies that the $\mathrm{CO}$ and $\mathrm{TiC}$ aren't primarily obtained by reaction (8). As mentioned above, the $\mathrm{CO}$ contents varies with the current if there aren't other side reactions, so the contents of $\mathrm{CO}$ decrease with the decline of current at first $1 \mathrm{~h}$ electrolysis as shown in Fig. 3 and Table-1. In other words, the formation of $\mathrm{CO}$ is mainly through reaction (2) at first $1 \mathrm{~h}$. However, the $\mathrm{CO}$ contents continuous increase no matter how the current changes after $1 \mathrm{~h}$ as detailed in Fig. 3 and Table-1. This means that the formation of CO is both by reaction (2) and (3) after $1 \mathrm{~h}$ electrolysis. Although the current decreases and basically constant behind $210 \mathrm{~min}$, the content of CO enlarge obviously with the increase of time, this implies that the quantity of $\mathrm{CO}$ obtained by reaction (3) is much more than that of by reaction (2) in the later of electrolysis.

The $\mathrm{O}^{2-}$ formed by reaction (7) migrates to anode, which results in the recycle reaction and then repeatedly consumes the electric current so as to influence the electrolysis efficiency. Meanwhile, a gas membrane retention layer is formed for the concentration of $\mathrm{CO}_{2}$ near the anode which causes a thickness greater than $10^{-4} \mathrm{~cm}$ to be formed ${ }^{66}$. The whole reaction process is equivalent to a gas electrode. It generates over-potential and it also affects the current efficiency.

The formation of off-gas and its effect are summarized in Fig. 6. The side reactions are subjected to the $\mathrm{CO}_{2}$ and $\mathrm{CO}$ without venting in time. And thus these influence the electrolysis efficiency and the purity of the products.

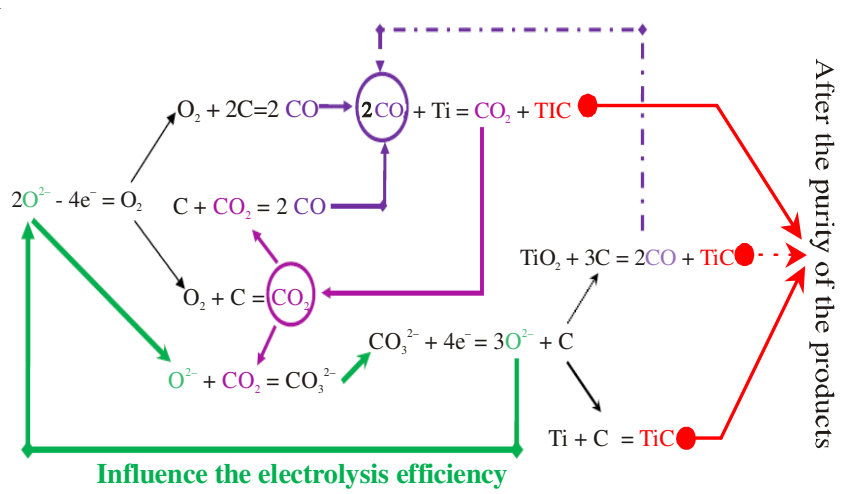

Fig. 6. Schematic diagram of reactions and its impacts

Possible solution: Fig. 7 showed the gas-liquid-solid three-phase interfaces (3PIs) near the graphite anode. Because of the stillness of molten salt and the porosity of the graphite anode material, the thicker gas film is formed at the 3PIs and such that the $\mathrm{CO}$ and $\mathrm{CO}_{2}$ are not easy removal. In addition to this, the argon gas accesses downwardly as shown in Fig. 1 is another reason, the direction of argon flow is opposite to that of the off-gas and such that hinders the outflow of $\mathrm{CO}$ and $\mathrm{CO}_{2}$. Lastly, there is not collection unit at the exhaust port as shown in Fig. 1. So the discharge of $\mathrm{CO}$ and $\mathrm{CO}_{2}$ is lagged.

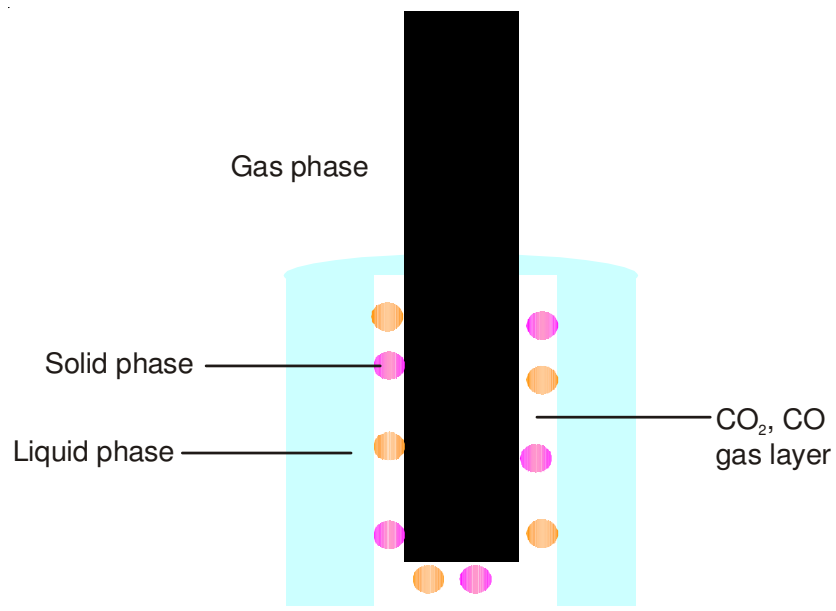

Fig. 7. Schematic diagram near the anode

In order to solve the effect of above three reasons, the following improvements as detailed in Fig. 8 may be necessary. Comparisons of the Figs. 1 and Fig. 8, there are agitation, high density graphite anode, inlet gas direction and quantity, outlet shape differences.

These improvements will bring some advantages. Firstly, the use of mechanical agitation and high density graphite anode can reduce the adsorption of $\mathrm{CO}$ and $\mathrm{CO}_{2}$ near the anode, so these gases can escape timely from molten to the hearth. Secondly, argon gas accesses upwardly, the argon gas and offgas have the same flow direction and such that the argon gas is the carrier gas of $\mathrm{CO}_{2}$ and $\mathrm{CO}$. Circular ventilation pipe have a plurality of cavernous mouths, which make argon gas in the furnace uniformly and rapidly. The improvements of inlet gas direction and quantity are conductive to the discharge of off-gas from hearth to outside. Thirdly, funnel-shaped outlet can make off-gas out of hearth easily and quickly. 


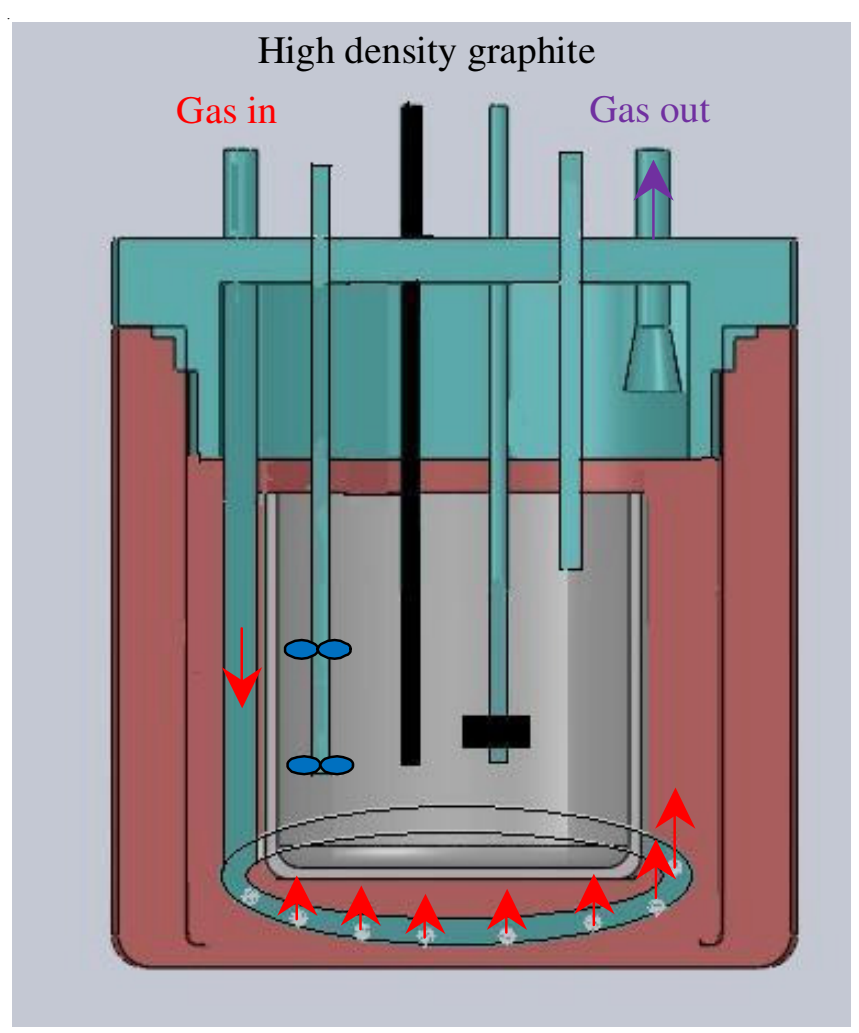

Fig. 8. Improved device

\section{Conclusion}

There are two ways to form CO during electrolysis. Some of them are formed by the reaction between graphite anode and oxygen produced nearby anode, which is the main anodic reaction. The other parts result from the side reactions. The side reactions are subjected to the $\mathrm{CO}_{2}$ and $\mathrm{CO}$ without venting in time. And thus these influence the electrolysis efficiency and the purity of the products.

The use of agitation and high density graphite anode maybe favor of the $\mathrm{CO}_{2}$ and $\mathrm{CO}$ to escape timely from molten to the hearth. The change of inlet gas direction and quantity and the use of funnel-shaped outlet can make off-gas out of hearth easily and quickly.

\section{ACKNOWLEDGEMENTS}

This work is financially supported by the Fundamental Research Funds for the Central Universities (Project No. CDJXS11221172, No.CDJZR10220003).

\section{REFERENCES}

1. D.J. Fray, G.Z. Chen and T.W. Farthing, Nature, 407, 361 (2000). PubMed

2. X. Ge, X. Wang and S. Seetharaman, Electrochim. Acta, 54, 4397 (2009).

3. B. Claux, J. Serp and J. Fouletier, Electrochim. Acta, 56, 2771 (2011).

4. Y. Castrillejo, M.R. Bermejo, P. Díaz Arocas, A.M. Martínez and E. Barrado, J. Electroanal. Chem., 575, 61 (2005).

5. B.Y. Kim, D.H. Lee, J.Y. Lee and J.-I. Yun, Electrochem. Commun., 12, 1005 (2010)

6. P. Kim, H.W. Xie, Y.C. Zhai, X. Zou and X. Lang, J. Appl. Electrochem., 42, 257 (2012)

7. J.M. Hur, S.S. Hong and H. Lee, J. Radioanal. Nucl. Chem., 295, 851 (2013).

8. W. Bixia, Z. Lian, L. Xinzhe, Z. Xicheng and C. Jingtao, Rare Metals Mater. Eng., 39, 1513 (2010).
9. D.T.L. Alexander, C. Schwandt and D.J. Fray, Electrochim. Acta, 56, 3286 (2011)

10. K.S. Mohandas and D.J. Fray, J. Appl. Electrochem., 41, 321 (2011).

11. R. Bhagat, D. Dye, S.L. Raghunathan, R.J. Talling, D. Inman, B.K. Jackson, K.K. Rao and R.J. Dashwood, Acta Mater., 58, 5057 (2010).

12. M. Gibilaro, J. Pivato, L. Cassayre, L. Massot, P. Chamelot and P. Taxil, Electrochim. Acta, 56, 5410 (2011).

13. Z.Q. Li, L.Y. Ru, C.G. Bai, N. Zhang and H. Wang, Int. J. Min. Metall. Mater, 19, 636 (2012).

14. W. Li, X.B. Jin, F.L. Huang and G.Z. Chen, Angew. Chem. Int. Ed., 49, 3203 (2010).

15. Z.Q. Li, N. Zhang, C.G. Bai, D.M. Jian, L.Y. Ru and H.H. Wang, Asian J. Chem., 23, 4932 (2011).

16. K.S. Mohandas and D.J. Fray, Metall. Mater. Trans. B, Process Metall. Mater. Proc. Sci., 40, 685 (2009).

17. J.J. Qiu, S. Chen, Y.K. Wu and L.J. Wang, Chin. J. Rare Met., 35, 78 (2011).

18. A.M. Abdelkader and D.J. Fray, Electrochim. Acta, 64, 10 (2012).

19. Z.F. Cai, Z.M. Zhang, Z.C. Guo and H.- Tang, Int. J. Min. Metall. Mater., 19, 499 (2012).

20. T. Wu, W. Xiao, X.B. Jin, C. Liu, D. Wang and G.Z. Chen, Phys. Chem. Chem. Phys., 10, 1809 (2008).

21. X.Y. Yan and D.J. Fray, J. Electrochem. Soc., 152, D12 (2005).

22. R. Barnett, K.T. Kilby and D.J. Fray, Metall. Mater. Trans. B, Process Metall. Mater. Proc. Sci., 40, 150 (2009).

23. Q.S. Song, Q. Xu, X. Kang, J. Du and Z. Xi, J. Alloys Comp., 490, 241 (2010).

24. E. Gordo, G.Z. Chen and D.J. Fray, Electrochim. Acta, 49, 2195 (2004).

25. G.Z. Chen, E. Gordo and D.J. Fray, Metall. Mater. Trans. B, Process Metall. Mater. Proc. Sci., 35, 223 (2004).

26. C.Y. Chen and X.G. Lu, Acta Metall. Sin., 44, 145 (2008).

27. G.M. Li, D.H. Wang, X.B. Jin and G. Chen, Electrochem. Commun., 9, 1951 (2007)

28. W. Xu and L. Chunfa, Int. J. Refract. Met. Hard Mater., 31, 205 (2012).

29. T. Wang, H.P. Gao, X.B. Jin, H. Chen, J. Peng and G.Z. Chen, Electrochem. Commun., 13, 1492 (2011).

30. H.Y. Yin, D.Y. Tang, H. Zhu, Y. Zhang and D. Wang, Electrochem. Commun., 13, 1521 (2011).

31. A. Cox and D.J. Fray, J. Appl. Electrochem., 38, 1401 (2008).

32. D.H. Wang, A.J. Gmitter and D.R. Sadoway, J. Electrochem. Soc., 158, E51 (2011)

33. R.F. Descallar-Arriesgado, N. Kobayashi, T. Kikuchi and R.O. Suzuki, Electrochim. Acta, 56, 8422 (2011).

34. X.Y. Yan and D.J. Fray, J. Appl. Electrochem., 39, 1349 (2009).

35. E. Ergul, I.S. Karakaya and M. Erdogan, J. Alloys Comp., 509, 899 (2011).

36. W. Xiao, X. Wang, H.Y. Yin, H. Zhu, X. Mao and D. Wang, RSC Adv, 2, 7588 (2012).

37. E. Juzeliunas, A. Cox and D.J. Fray, Electrochim. Acta, 68, 123 (2012).

38. W. Xiao, X.H. Jin, Y. Deng, D. Wang and G.Z. Chen, J. Electroanal. Chem., 639, 130 (2010).

39. X.B. Liu, Z.T. Luo, P.F. Xing et al., Chinese Patent, Appl. 20120425 (2012).

40. R. Bhagat, M. Jackson, D. Inman and R. Dashwood, J. Electrochem. Soc., 155, E63 (2008).

41. X.L. Zou, X.G. Lu, Z.F. Zhou, C. Li and W. Ding, Electrochim. Acta, 56, 8430 (2011).

42. C.-F. Liu, C.-H. Lin, C.-C. Lin, Y.-H. Lin, C.-F. Chen and S.-C. Lin, Chin. J. Rare Met., 33, 779 (2009).

43. M. Panigrahi, A. Iizuka, E. Shibata and T. Nakamura, J. Alloys Comp., 550, 545 (2013).

44. R.M. Shi, C.G. Bai and J.H. Du, Rare Metal., Mater. Des., 40, 2043 (2011).

45. S.Q. Jiao, L.L. Zhang, H.M. Zhu and D.J. Fray, Electrochim. Acta, 55, 7016 (2010).

46. B.X. Wang, R. Bhagat, X.Z. Lan and R.J. Dashwood, J. Electrochem. Soc., 158, D595 (2011).

47. A.M. Abdelkader and D.J. Fray, Electrochim. Acta, 55, 2924 (2010).

48. W. Chen, S.B. Wang, J.B. Ge, S. Jiao and H. Zhu, Intermetallics, 25, 66 (2012).

49. G.H. Qiu, D.H. Wang, X.B. Jin and G.Z. Chen, Electrochim. Acta, 51, 5785 (2006).

50. M. Gibilaro, L. Massot, P. Chamelot and P. Taxil, J. Alloys Comp., 471, 412 (2009). 
51. Y. Zhang, H.Y. Yin, S.D. Zhang, D. Tang, Z. Yuan, T. Yan, W. Zheng and D. Wang, J. Rare Earths, 30, 923 (2012).

52. X. Kang, Q. Xu, X.M. Yang and Q. Song, Mater. Lett., 64, 2258 (2010).

53. L. Dai, S. Wang, Y.H. Li, L. Wang and G.- Shao, Nonferrous Met. Soc. China, 22, 2007 (2012).

54. D.J.S. Hyslop, A.M. Abdelkader, A. Cox and D.J. Fray, Acta Mater., 58, 3124 (2010).

55. X. Wang and Y.C. Zhai, Chin. J. Rare Met., 32, 649 (2008).

56. M. Li, B. Chang, Z. Zhen, P.-J. Qin, W.-K. Liu and X.-L. Tong, Chin. J. Rare Met., 39, 301 (2011).

57. W. Li, X.B. Jin, F.M. Xiao, et al., Analysis of the C sources in the preparation of Ti from molten electrolysis of $\mathrm{TiO}_{2}$, Proceedings of the 16th National Conference on Electrochemistry (2011).

58. V.A. Lebedev, V.I. Sal'nikov, I.A. Sizikov and D.A. Rymkevich, Russ. J. Appl. Chem., 80, 1503 (2007).
59. S.M. Jeong, H.S. Shin, S.H. Cho, J.-M. Hur and H.S. Lee, Electrochim. Acta, 54, 6335 (2009).

60. M. Gibilaro, L. Cassayre, O. Lemoine, L. Massot, O. Dugne, R. Malmbeck and P. Chamelot, J. Nucl. Mater., 414, 169 (2011).

61. M. Iizuka, T. Inoue, M. Ougier and J.-P. Glatz, J. Nucl. Sci. Technol., 44, 801 (2007).

62. K.T. Kilby, S.Q. Jiao and D.J. Fray, Electrochim. Acta, 55, 7126 (2010).

63. D.L. Ye and J.H. Hu, Practical Handbook of Thermodynamic Data of Inorganic, China, Beijing, p. 1047 (2002).

64. K. Le Van, H. Groult, F. Lantelme, M. Dubois, D. Avignant, A. Tressaud, S. Komaba, N. Kumagai and S. Sigrist, Electrochim. Acta, 54, 4566 (2009).

65. H. Groult, B. Kaplan, F. Lantelme, S. Komaba, N. Kumagai, H. Yashiro, T. Nakajima, B. Simon and A. Barhoun, Solid State Ion., 177, 869 (2006).

66. H.L. Hu and N. Li, Electrochemical Measurements, China, Beijing, p. 26 (2007). 